\title{
Restriction pattern of the major outer-membrane protein gene provides evidence for a homogeneous invasive group among ruminant isolates of Chlamydia psittaci
}

\author{
Erick Denamur, ${ }^{1 *}$ Chalom Sayada, ${ }^{1}$ Armel Souriau, ${ }^{2}$ Jeanne Orfila, ${ }^{3}$ Annie Rodolakis ${ }^{2}$ \\ and JACQUES ELION ${ }^{1}$ \\ ${ }^{1}$ Laboratoire de Biochimie Génétique and INSERM U 120, Hôpital Robert Debré, 48 boulevard Sérurier, 75935 Paris \\ Cedex 19, France \\ ${ }^{2}$ Station de Pathologie de la Reproduction, Institut National de la Recherche Agronomique, 37380 Nouzilly, France \\ ${ }^{3}$ Laboratoire de Microbiologie, Faculté de Médecine, 80036 Amiens, France
}

(Received 22 April 1991; revised 26 June 1991; accepted 29 July 1991)

\begin{abstract}
Thirty-six ruminant isolates of Chlamydia psittaci, previously classified as invasive or non-invasive in a mouse model of virulence, were compared by analysing $A l u I$ restriction patterns of the major outer-membrane protein (MOMP) gene after DNA amplification by the polymerase chain reaction. The 24 invasive isolates, although from various origins, all belonged to serotype 1 and represented a strictly homogeneous group sharing a specific MOMP-gene restriction pattern that was not observed in the non-invasive strains. On the other hand, the 12 noninvasive strains, although all belonging to serotype 2, constituted a heterogeneous group with eight distinct MOMP-gene restriction patterns. However, all eight patterns shared a 180 bp fragment or the corresponding restricted fragments of 110 and $70 \mathrm{bp}$. MOMP-gene restriction patterns also clearly distinguished the ruminant strains from an avian $C$. psittaci isolate, a $C$. pneumoniae isolate and two $C$. trachomatis isolates which were studied for comparison. The homogeneous character of the invasive $C$. psittaci strains argues strongly for their genetic relatedness. Our results illustrate the usefulness of the MOMP-gene restriction mapping in typing chlamydiae.
\end{abstract}

\section{Introduction}

The genus Chlamydia is divided into three species, Chlamydia trachomatis, $C$. psittaci and C. pneumoniae (Moulder et al., 1984; Grayston et al., 1989). Of these, $C$. trachomatis and $C$. pneumoniae are well-characterized species. However, C. psittaci represents a heterogeneous group including isolates of both mammalian and avian origin. Several attempts have been made at differentiating members of the species $C$. psittaci. DNA-DNA reassociation studies (Kingsbury \& Weiss, 1968; Cox et al., 1988; Fukushi \& Hirai, 1989) indicate substantial differences within the $C$. psittaci group and suggest the existence of at least four separate genospecies. Isolates studied included those of avian origin and ovine abortion strains, feline pneumonitis isolates, isolates from ovine polyarthritis and cattle infections, and a guinea pig inclusion conjunctivitis isolate. Other genotypic studies, as well as phenotypic data, basically agree with this classification and provide an enhanced discrimination of

Abbreviation: MOMP, major outer-membrane protein. epidemiological interest. Genotypic characterization has included plasmid analysis (McClenaghan et al., 1988), restriction endonuclease analysis of total DNA or of specific DNA regions (McClenaghan et al., 1984; Campbell et al., 1987; Timms et al., 1988; Girges et al., 1988; Fukushi \& Hirai, 1989; Andersen, 1991a) and sequencing of the major outer-membrane protein (MOMP) gene (Pickett et al., 1988; Herring et al., 1989; Zhang et al., 1989). Phenotypic data were obtained by biotyping (Spears \& Storz, 1979; Allan \& Pearce, 1983), polypeptide profile analysis (McClenaghan et al., 1991) and serotyping (Schachter et al., 1974, 1975; Eb \& Orfila, 1982; Perez-Martinez \& Storz, 1985; Eb et al., 1986; Fukushi et al., 1987; Fukushi \& Hirai, 1988; Andersen \& Van Deusen, 1988; Andersen, 1991b).

In ruminants, $C$. psittaci is associated with a wide range of infections, including abortion, epididymitis, pneumonia, conjunctivitis, polyarthritis, encephalitis, enteritis and clinically inapparent, intestinal infection. Abortions due to chlamydial infection have major economic implications in ruminant breeding. In order to establish the role of chlamydiae isolated from the faeces 
of healthy ruminants in the epidemiology of abortive chlamydiosis, we previously reported a murine model to study virulence. This model (Rodolakis et al., 1989) distinguishes two categories of strains: invasive strains, most often isolated from symptomatic infections, induce splenomegaly and splenic infection following subcutaneous inoculation in the mouse footpad, whereas noninvasive strains, mostly of intestinal origin, neither induce a change in spleen weight nor a splenic infection. This difference of invasiveness in the mouse model is associated with dissimilar protein patterns as obtained by PAGE (Buzoni-Gatel et al., 1989).

Recently, the polymerase chain reaction (PCR) has been applied to the detection and differentiation of the three Chlamydia species by using primers specific for the MOMP gene (Dutilh et al., 1989; Holland et al., 1990). Furthermore, preliminary communications have reported intra-species characterization of $C$. trachomatis (Frost et al., 1990) and C.psittaci (Herring et al., 1990) by
Alul restriction mapping of the PCR-amplified MOMP gene.

In this paper, we report on the AluI restriction mapping of the MOMP gene to study 36 ruminant $C$. psittaci isolates previously characterized in the murine model for virulence. An avian C. psittaci, a C. pneumoniae isolate and two $C$. trachomatis isolates were also studied for comparison.

\section{Methods}

Chlamydial strains. We studied 36 ruminant isolates of $C$. psittaci including the invasive and non-invasive reference strains AB7 and $\mathrm{iB} 1$, respectively. Among them, 24 strains were invasive in our mouse model and 12 were non-invasive. One avian $C$. psittaci, a $C$. pneumoniae isolate and two $C$. trachomatis isolates were included for comparison. The origins of each isolate, together with other relevant information, are summarized in Table 1.

Chlamydial strains were grown in mycoplasma-free McCoy cells in plastic flasks $(150 \mathrm{ml}) ; 4$ and 12 flasks were used for invasive and non-

Table 1. Characteristics of the chlamydial strains used in this study

\begin{tabular}{|c|c|c|c|c|}
\hline $\begin{array}{l}\text { Strain* and } \\
\text { associated } \\
\text { disease }\end{array}$ & $\begin{array}{c}\text { Geographical } \\
\text { origin }\end{array}$ & $\begin{array}{l}\text { Invasive- } \\
\text { ness for } \\
\text { mice† }\end{array}$ & Serotype $\ddagger$ & $\begin{array}{l}\text { MOMP-gene } \\
\text { restriction } \\
\text { pattern }\end{array}$ \\
\hline C. psittaci & & & & \\
\hline $\begin{array}{l}\text { Ovine abortion } \\
\text { AB7 } \\
\text { AB4 } \\
\text { AB6 } \\
\text { AB8 } \\
\text { AB9 } \\
\text { AB10 } \\
\text { AB13 } \\
\text { AB15 } \\
\text { A22 } \\
\text { S26/3 } \\
\text { H574 } \\
\text { Q18 } \\
\text { PS22 }\end{array}$ & $\begin{array}{l}\text { France } \\
\text { France } \\
\text { France } \\
\text { France } \\
\text { France } \\
\text { France } \\
\text { France } \\
\text { France } \\
\text { Scotland } \\
\text { Scotland } \\
\text { Scotland } \\
\text { France } \\
\text { USA }\end{array}$ & $\begin{array}{l}+ \\
+ \\
+ \\
+ \\
+ \\
- \\
+ \\
+ \\
+ \\
+ \\
+ \\
+ \\
+\end{array}$ & $\begin{array}{l}1 \\
1 \\
1 \\
1 \\
1 \\
2 \\
1 \\
1 \\
1 \\
1 \\
1 \\
1 \\
1\end{array}$ & $\begin{array}{l}\text { A } \\
\text { A } \\
\text { A } \\
\text { A } \\
\text { A } \\
\text { B } \\
\text { A } \\
\text { A } \\
\text { A } \\
\text { A } \\
\text { A } \\
\text { A } \\
\text { A }\end{array}$ \\
\hline $\begin{array}{l}\text { Bovine abortion } \\
\text { AV1 }\end{array}$ & France & + & 1 & A \\
\hline $\begin{array}{l}\text { Caprine abortion } \\
\text { AC1 } \\
\text { AC2 } \\
\text { AC3 }\end{array}$ & $\begin{array}{l}\text { France } \\
\text { France } \\
\text { France }\end{array}$ & $\begin{array}{l}+ \\
+ \\
+\end{array}$ & $\begin{array}{l}1 \\
1 \\
1\end{array}$ & $\begin{array}{l}\mathrm{A} \\
\mathrm{A} \\
\mathrm{A}\end{array}$ \\
\hline $\begin{array}{l}\text { Thermo-sensitive } \\
\text { 1B } \\
\text { 1H }\end{array}$ & $\begin{array}{l}\text { mutant } \\
\text { Mutant of } A B 7 \\
\text { Mutant of } A B 7\end{array}$ & $\begin{array}{l}+ \\
+\end{array}$ & $\begin{array}{l}1 \\
1\end{array}$ & $\begin{array}{l}\text { A } \\
\text { A }\end{array}$ \\
\hline $\begin{array}{l}\text { Ovine arthritis } \\
1 \mathrm{H} 77^{a} \\
\text { LW-679 }\end{array}$ & $\begin{array}{l}\text { Scotland } \\
\text { USA }\end{array}$ & $\begin{array}{l}+ \\
-\end{array}$ & $\begin{array}{l}1 \\
2\end{array}$ & $\begin{array}{l}\text { A } \\
\text { B }\end{array}$ \\
\hline
\end{tabular}

\begin{tabular}{|c|c|c|c|c|}
\hline $\begin{array}{l}\text { Strain* and } \\
\text { associated } \\
\text { disease }\end{array}$ & $\begin{array}{l}\text { Geographical } \\
\text { origin }\end{array}$ & $\begin{array}{l}\text { Invasive- } \\
\text { ness for } \\
\text { micet }\end{array}$ & Serotype & $\begin{array}{l}\text { MOMP-gene } \\
\text { restriction } \\
\text { pattern }\end{array}$ \\
\hline \multicolumn{5}{|c|}{ Ovine conjunctivitis } \\
\hline $\mathrm{OCl}$ & France & + & 1 & A \\
\hline $824^{a}$ & Scotland & - & 2 & $\mathrm{C}$ \\
\hline \multicolumn{5}{|l|}{ Ovine pneumonia } \\
\hline $109-75^{e}$ & France? & + & 1 & A \\
\hline \multicolumn{5}{|c|}{ Ovine epididymitis } \\
\hline VB 1 & France & + & 1 & A \\
\hline \multicolumn{5}{|c|}{ Intestinal (faeces of healthy sheep) } \\
\hline $\mathrm{iB1}$ & France & - & 2 & D \\
\hline iB3 & France & - & 2 & $\mathrm{E}$ \\
\hline ¡B4 & France & - & 2 & $\mathbf{F}$ \\
\hline iB5 & France & - & 2 & G \\
\hline R69r & Northern Ireland & - & 2 & $\mathbf{H}$ \\
\hline W73f & Northern Ireland & - & 2 & $\mathbf{H}$ \\
\hline $\mathrm{MO}-907^{d}$ & USA & + & 1 & A \\
\hline \multicolumn{5}{|c|}{ Intestinal (faeces of healthy goats) } \\
\hline $\mathrm{iCl}$ & France & + & 1 & A \\
\hline iC2 & France & - & 2 & I \\
\hline iC3 & France & - & 2 & I \\
\hline $\mathrm{iC4}$ & France & - & 2 & I \\
\hline \multicolumn{5}{|c|}{ Pigeon systemic infection } \\
\hline Loth $^{\theta}$ & Netherlands & & 11 & $\mathbf{J}$ \\
\hline \multicolumn{5}{|l|}{ C. trachomatis } \\
\hline $\begin{array}{l}\text { Mouse Biovar } \\
\text { MoPn ATCC } \\
\text { VR } 123\end{array}$ & USA & & & $\mathbf{K}$ \\
\hline $\begin{array}{l}\text { LGV Biovar } \\
\text { L2/434/Bu }\end{array}$ & USA & & & L \\
\hline C. pneumoniae & & & & \\
\hline IOL-207i & Iran & & & $\mathbf{M}$ \\
\hline
\end{tabular}

* Sources of strains were as follows: $a$, I. D. Aitken, Moredun Research Institute, Edinburgh, Scotland, UK ; $b$, P. Giroud, Institut Pasteur, Paris, France; $c$, J. Schachter, University of California, San Francisco, USA; $d$, J. Storz (Spears \& Storz, 1979); $e$, P. Russo, Laboratoire de Pathologie des Petits Ruminants Sophia Antipolis, France; $f$, M. S. McNulty Veterinary Research Laboratories, Belfast, Northern Ireland, UK; $g$, F. Dekking, Hygiene Institut, Amsterdam, The Netherlands; $h$, S. P. Wang, University of Washington, Seattle, USA; $i$, J. D. Threharne, Institute of Opthalmology, London, UK.

† Rodolakis et al. (1989).

$\ddagger$ Determined as in Eb et al. (1986). 
invasive strains, respectively. Cell monolayers were infected with about $10^{7}$ plaque forming units (p.f.u.) (Banks et al., 1970) of yolk-sacpropagated chlamydiae and incubated at $37^{\circ} \mathrm{C} ; 7 \mathrm{~d}$ after inoculation the chlamydia-containing medium was gently collected and replaced with fresh medium. At 2 weeks, cells were detached from the plastic, disrupted by vigorous shaking with glass-beads and harvested with the medium. After both harvests, chlamydiae were immediately pelleted at $15000 \mathrm{~g}$ for $2 \mathrm{~h}$ at $4{ }^{\circ} \mathrm{C}$, suspended in $1.5 \mathrm{ml}$ phosphate/glutamine/ sucrose buffer, pH 7.6 (Madeley, 1977) to an approximate concentration of $10^{8}$ p.f.u. $\mathrm{ml}^{-1}$ and stored at $-70^{\circ} \mathrm{C}$.

$P C R$ analysis of the MOMP gene. DNA was obtained by lysis of $1 \mu \mathrm{l}$ of the chlamydial preparation in $250 \mu \mathrm{l}$ of buffer containing $50 \mathrm{~mm}-$ $\mathrm{KCl}, 10 \mathrm{~mm}-\mathrm{Tris} / \mathrm{HCl}$ (pH 8.3), $2.5 \mathrm{~mm}-\mathrm{MgCl}_{2}, 0.45 \%$ Nonidet $\mathrm{P}-40$, $0.45 \%$ Tween 20 and $60 \mu \mathrm{g}$ proteinase $\mathrm{K} \mathrm{ml}^{-1}$. Positive displacement pipettes were used to minimize sample carry-over and samples were prepared in an externally vented hood used only for this purpose. The DNA preparation was incubated at $56^{\circ} \mathrm{C}$ for $60 \mathrm{~min}$ and proteinase $\mathrm{K}$ was heat-inactivated at $95^{\circ} \mathrm{C}$ for $10 \mathrm{~min}$. A pair of oligonucleotide primers for the MOMP gene, CTU/CTL [CTU, 5'-ATGAAAAAACTCTTGAAATCGG-3'; CTL, 5'-CAAGATTTTCTAGA(T/C)TTCAT(C/T)TTGTT-3'] was chosen from the highly conserved regions of the published DNA sequences for the MOMP gene of C. trachomatis (Stephens et al., 1987; Yuan et al., 1988) and C. psittaci (Pickett et al., 1988; Herring et al., 1989; Zhang et al., 1989) strains. This allowed amplification of a $1 \mathrm{kbp}$ fragment. Oligonucleotides were synthesized by the phosphoramidite method on a DNA synthesizer (Applied Biosystems). A $25 \mu \mathrm{l}$ vol. of the DNA preparation was subjected to PCR in a $100 \mu \mathrm{l}$ final reaction mixture containing: $10 \mathrm{~mm}$ Tris/HCl, pH 8.3; $200 \mu \mathrm{M}$ (each) dATP, dCTP, dGTP, dTTP; $200 \mu \mathrm{M}$ (each) CTU and CTL; $2.5 \mathrm{mM}-\mathrm{MgCl}_{2} ; 50 \mathrm{mM}-\mathrm{KCl}$; and 2.5 units of Thermus aquaticus DNA polymerase (Perkin-Elmer/Cetus) overlayed with $100 \mu \mathrm{l}$ of mineral oil. In order to improve specificity, DNA was added last after heating the amplification mixture at $80^{\circ} \mathrm{C}$ (Mullis, 1990). Samples were subjected to 30 cycles of amplification in a DNA Thermal Cycler (Perkin-Elmer/Cetus). Cycling conditions were as follows: denaturation, $1 \mathrm{~min}$ at $94^{\circ} \mathrm{C}$; primer annealing, $1 \mathrm{~min}$ at $48^{\circ} \mathrm{C}$; and primer extension, $2 \mathrm{~min}$ at $72^{\circ} \mathrm{C}$. Three negative controls were systematically included in each series: a non-infected McCoy cell preparation; lysis buffer with proteinase $\mathrm{K}$ alone; and water. To assess the amplification, a $5 \mu \mathrm{l}$ vol. of the PCR reaction was subjected to electrophoresis on a $1.2 \%$ agarose gel stained with ethidium bromide and photographed under UV illumination. DNA molecular size marker III (Boehringer) was used. Restriction endonuclease digestion with $A l u \mathrm{I}$ (Boehringer) was performed on $5 \mu \mathrm{l}$ aliquots of the amplified samples and the products were analysed by electrophoresis on $8 \%(w / v)$ polyacrylamide gels, stained and photographed as above. DNA molecular mass marker $\mathrm{V}$ (Boehringer) was used as size marker.

\section{Results}

For all the 40 Chlamydia strains studied, the PCR reaction produced an amplified DNA fragment of the expected size. No difference in size was seen on the agarose gels whatever the strain (Fig. 1). No PCR products were obtained with the non-infected cells.

Digestion of the MOMP gene by AluI generated 13 different restriction patterns (A to $M$ ) (Fig. 2, Table 1). Analysis of $A l u \mathrm{I}$ fragments in the 410 to $64 \mathrm{bp}$ size-range sufficed to differentiate the strains studied and fragments of smaller sizes were not considered. A summary of the fragment sizes obtained is given in Table 2.
Table 2. Sizes of the restriction fragments of the PCRamplified Chlamydia MOMP genes

Values given are those deduced from our experimental data. For C. pneumoniae IOL-207, C. trachomatis $\mathrm{L} 2 / 434 / \mathrm{Bu}$ and $C$. psittaci S26/3 strains, experimental values are in agreement with the published MOMP-gene sequences for these strains.

\begin{tabular}{ll}
\hline \hline Strains & \multicolumn{1}{c}{ Restriction fragment sizes (bp) } \\
\hline C. psittaci & \\
Invasive strains & $198,171,159,84,82,81,78,75$ \\
LW-679, AB10 & $350,270,180,135$ \\
824 & $290,250,180,135,125$ \\
iB1 & $290,250,135,125,110,70$ \\
iB3 & $293,250,180,160,135$ \\
iB5 & $290,180,155,125,115,84$ \\
iB4 & $275,230,145,120,110,70$ \\
iC4, iC3, iC2 & $290,198,180,150,95,90,75$ \\
R69, W73 & $293,150,125,110,82,70$ \\
Loth & $410,290,110,100,84$ \\
C. trachomatis & \\
MoPn & $270,250,132,110,67,64$ \\
L2/434/Bu & $227,225,132,102,96$ \\
C. pneumoniae & \\
IOL-207 & $239,204,162,141,129,97,81$ \\
\hline \hline
\end{tabular}

All the 24 invasive $C$. psittaci isolates gave the same pattern (pattern A). The 12 non-invasive $C$. psittaci isolates exhibited eight distinct patterns (B to I). However, all these eight patterns shared a common fragment of $180 \mathrm{bp}$ (patterns B, C, E, G and I) or the corresponding restricted fragments of 110 and $70 \mathrm{bp}$ (patterns D, F and H) which are not found in the outer patterns. Patterns C and D (C. psittaci strains 824 and iB1) were differentiated by this restriction site only, in the $180 \mathrm{bp}$ fragment. The avian C. psittaci isolate, the $C$. pneumoniae isolate and the two $C$. trachomatis isolates each gave a unique pattern ( $\mathrm{J}$ to $\mathrm{M}$, respectively).

\section{Discussion}

Serotyping of $C$. psittaci isolates provides a valuable tool for epidemiological studies but it requires access to specific reagents of restricted availability. Genotypic approaches, which are easy to perform without any specific reagents, are clearly needed for characterization of $C$. psittaci isolates. In the native DNA analyses previously reported for $C$. psittaci typing, cell cultures with or without chlamydial purification are necessary, both being costly and time-consuming. The PCR procedure allows direct MOMP-gene analysis without the need for cell culture and purification. Non-viable elementary bodies at a concentration of $10^{3} \mathrm{ml}^{-1}$ are sufficient to obtain directly a signal after ethidium bromide staining, without preliminary DNA extraction being required (data not shown). MOMP-gene AluI restriction patterns are obtained within $2 \mathrm{~d}$ without the need for a probing system. 


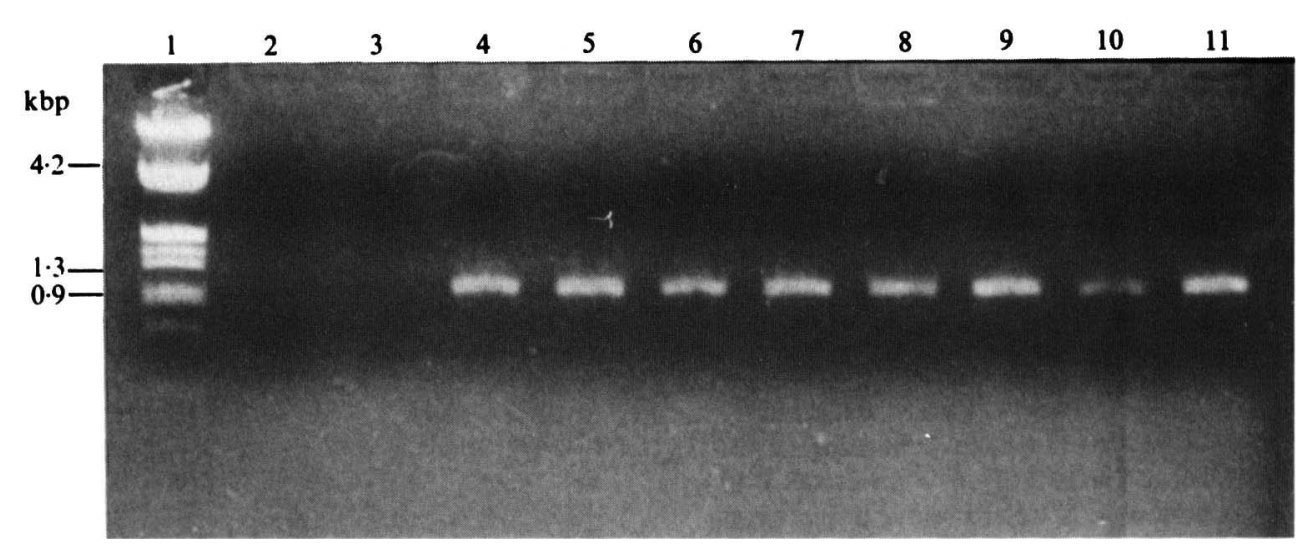

Fig. 1. Electrophoretic analysis of the PCR products after amplification of the MOMP gene. Molecular size marker III (1), non-infected McCoy cell preparation (2), lysis buffer alone (3), C. pneumoniae strain IOL-207 (4), C. trachomatis strain L2/434/Bu (5), C. psittaci strains Loth (6), iB4 (7), iB1 (8), LW-679 (9), S26/3 (10) and AB7 (11).

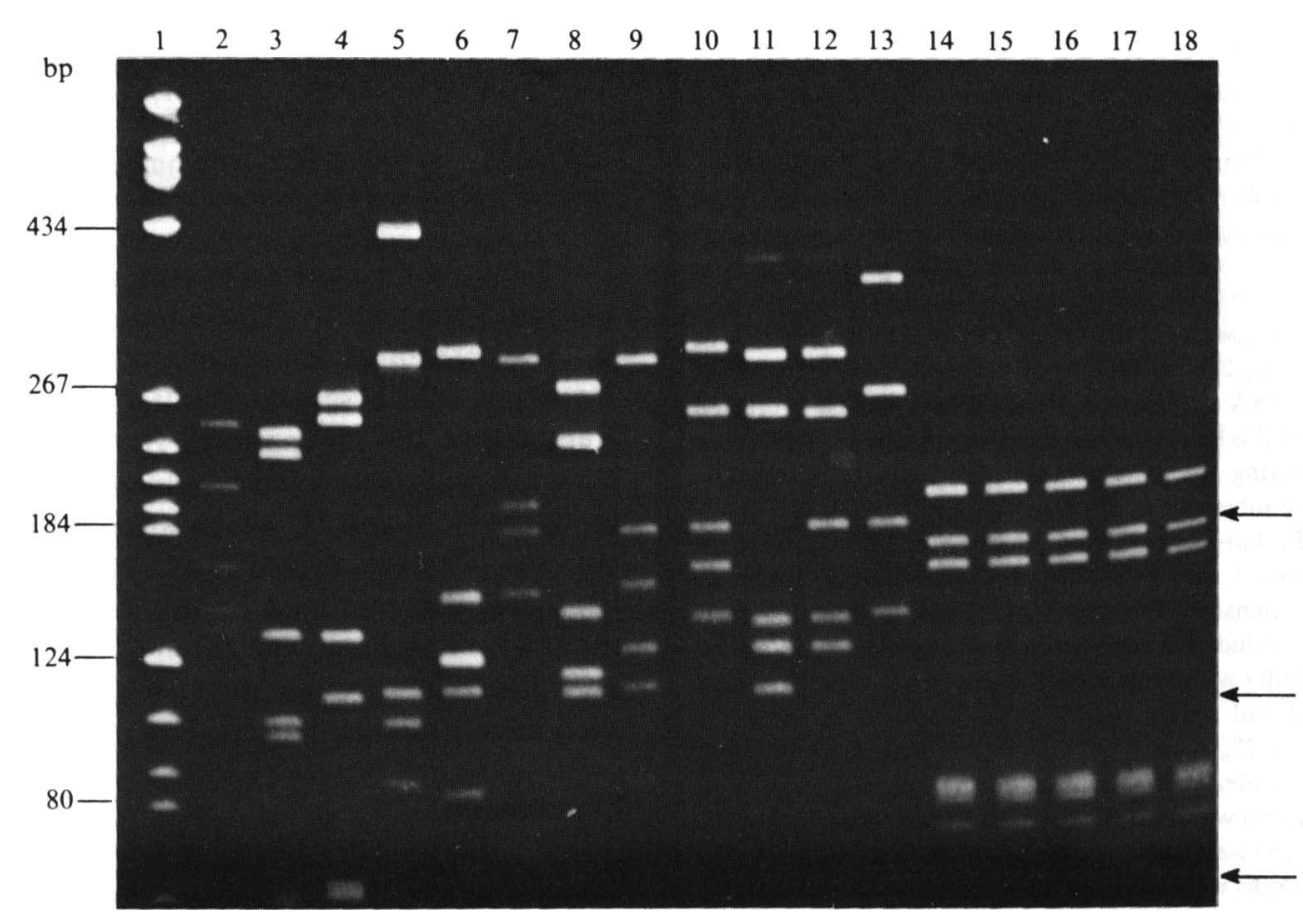

Fig. 2. MOMP-gene $A l u \mathrm{I}$ restriction patterns. Molecular size marker V (1), C. pneumoniae strain IOL-207 (2), C. trachomatis strains L2/434/Bu (3) and MoPn ATCC VR123 (4), C. psittaci strains Loth (5), R69 (6), iC4 (7), iB4 (8), iB5 (9), iB3 (10), iB1 (11), 824 (12), LW679 (13), AB7 (14), S26/3 (15), A22 (16), 1 H77 (17) and VB1 (18). Arrows correspond to the 180 bp fragment or the corresponding 110 and $70 \mathrm{bp}$ restricted fragments found in all the non-invasive ruminant strains.

Among the strains we studied, MOMP-gene AluI restriction mapping clearly distinguishes the $C$.pneumoniae isolate, the two $C$. trachomatis isolates one from the other and the avian $C$. psittaci isolate from the ruminant C. psittaci isolates (Table 1). Fragments obtained with $C$. pneumoniae IOL-207, C. trachomatis serovar L2 and $C$. psittaci $\mathrm{S} 26 / 3$ strains were in accordance with the published MOMP-gene sequences of these strains (Stephens et al., 1987; Herring et al., 1989; Carter et al., 1991). The avian strain C. psittaci Loth gave fragments identical to those predicted from the published $C$. psittaci
Cal 10 MOMP-gene sequence (Zhang et al., 1989). On the other hand, fragments obtained with the $C$. psittaci A22 strain did not correspond to the sequence data reported by Pickett et al. (1988) for the A22/M strain. In actual fact, the fragments were identical to those of $C$. psittaci $\mathrm{S} 26 / 3$. These data are in agreement with those of Herring et al. (1989) which suggested that the A22/M strain differed from the original A22 isolate and might correspond to a contaminant strain of avian origin.

The most striking feature of the present study is the genetic relatedness observed among the ruminant $C$. 
psittaci isolates previously classified as invasive in the murine model of virulence. Indeed, invasive strains all belong to a homogeneous group which exhibits the MOMP-gene restriction pattern A. It is noteworthy that these invasive strains shared an identical pattern whatever the host, the associated disease or the geographical origin (France, Scotland, UK, or the USA). McClenaghan et al. (1984) reported the homogeneity of ovine abortion strains by restriction endonuclease analysis of total DNA; three of their strains (A22, H574 and S26/3) were included in our series. In contrast, the non-invasive strains form a heterogeneous group which exhibits eight different MOMP-gene restriction patterns (B to I). However, among these eight patterns, there is a common $180 \mathrm{bp}$ fragment or the corresponding restricted fragments of 110 and $70 \mathrm{bp}$ which are specific for the non-invasive strains. Furthermore, among the ruminant strain patterns, any fragment longer than $198 \mathrm{bp}$ is characteristic of non-invasiveness.

A strict correspondence is observed between the MOMP-gene restriction pattern of the invasive strains and serotype 1 . On the contrary, non-invasive strains which all belonged to serotype 2 exhibit eight distinct MOMP-gene restriction patterns. MOMP-gene sequences in $C$. psittaci isolates are generally conserved except for four symmetrically spaced variable domains which precisely correspond to dominant immunological determinants (Zhang et al., 1989). It has been shown that the MOMP bears epitopes implicated in the serovar specificity of $C$. psittaci serovar 1 and 2 strains (Baghian et al., 1990). Our data suggest the possibility of some degree of heterogeneity in serotype 2 immunologic determinants. Furthermore, differences in infectivity of avian $C$. psittaci isolates have been reported to correlate with differences in MOMP molecular mass and antigenicity (Winsor \& Grimes, 1988).

The above findings clearly demonstrate the usefulness of MOMP-gene restriction mapping in typing chlamydiae. It could also provide a valuable tool to easily detect strain contamination (Herring et al., 1989).

We wish to thank Madame M. A. Corvoisier for her help in preparing this manuscript.

\section{References}

Allan, I. \& Pearce, J. H. (1983). Amino acid requirements of strains of Chlamydia trachomatis and C. psittaci growing in McCoy cells: relationship with clinical syndrome and host origin. Journal of General Microbiology 129, 2001-2007.

ANDERSEN, A. A. (1991a). Comparison of avian Chlamydia psittaci isolates by restriction endonuclease analysis and serovar-specific monoclonal antibodies. Journal of Clinical Microbiology 29, 244-249.

ANDersen, A. A. (1991 b). Serotyping of Chlamydia psittaci isolates using serovar-specific monoclonal antibodies with the microimmunofluorescence test. Journal of Clinical Microbiology 29, $707-711$
Andersen, A. A. \& Van Deusen, R. (1988). Production and partial characterization of monoclonal antibodies to four Chlamydia psittaci isolates. Infection and Immunity 56, 2075-2079.

Baghian, A., Shaffer, L. \& Storz, J. (1990). Antibody response to epitopes of chlamydial major outer membrane proteins on infectious elementary bodies and of the reduced polyacrylamide gel electrophoresis-separated form. Infection and Immunity 58, 1379-1383.

Banks, J. B., Eddie, J., Schachter, J. \& MeYer, K. F. (1970). Plaque formation by Chlamydia in L cells. Infection and Immunity 1, 259-262.

Buzoni-Gatel, D., Layachi, K. \& Rodolakis, A. (1989). Comparison of protein patterns between invasive and non-invasive ovine strains of Chlamydia psittaci. Research in Veterinary Science 46, 40-42.

Campbell, L. A., Kuo, C. C. \& Grayston, J. T. (1987). Characterization of the new Chlamydia agent, TWAR, as a unique organism by restriction endonuclease analysis and DNA-DNA hybridization. Journal of Clinical Microbiology 25, 1911-1916.

Carter, M. W., Al-Mahdawi, S. A. H., Giles, I. G., Treharne, J. D., Ward, M. E. \& Clarke, I. N. (1991). Nucleotide sequence and taxonomic value of the major outer membrane protein gene of Chlamydia pneumoniae IOL-207. Journal of General Microbiology 137, 465-475.

Cox, R. L., Kuo, C. C., Grayston, T. \& Campbell, L. A. (1988). Deoxyribonucleic acid relatedness of Chlamydia sp. strain TWAR to Chlamydia trachomatis and Chlamydia psittaci. International Journal of Systematic Bacteriology 38, 265-268.

Dutilh, B., Bebear, C., Rodriguez, P., Vekris, A., Bonnet, J. \& GARRET, M. (1989). Specific amplification of a DNA sequence common to all Chlamydia trachomatis serovars using the polymerase chain reaction. Research Microbiology 140, 7-16.

EB, F. \& Orfila, J. (1982). Serotyping of Chlamydia psittaci by the micro-immunofluorescence test: isolates of ovine origin. Infection and Immunity 37, 1289-1291.

Eb, F., Orfila, J., Milon, A. \& Geral, M. F. (1986). Intérêt épidémiologique du typage par immunofluorescence de Chlamydia psittaci. Annales de l'Institut Pasteur/Microbiologie 137B, 77-93.

Frost, E. H., Deslandes, S. \& BourgauX-Ramoisy, D. (1990). Typing Chlamydia isolates with the polymerase chain reaction. In Chlamydial Infections, Proceedings of the 7th International Symposium on Human Chlamydial Infections, pp. 499-502. Edited by W. R. Bowie, H. D. Caldwell, R. P. Jones, P. Mardh, G. L. Ridgway, J. Schachter, W. E. Stamm \& M. E. Ward. Cambridge: Cambridge University Press.

FukUSHI, H., NoJiRI, K. \& HiRaI, K. (1987). Monoclonal antibody typing of Chlamydia psittaci strains derived from avian and mammalian species. Journal of Clinical Microbiology 25, 1978-1981.

FUKUSHI, H. \& HIRAI, K. (1988). Immunochemical diversity of the major outer membrane protein of avian and mammalian Chlamydia psittaci. Journal of Clinical Microbiology 26, 675-680.

FUKUSHI, H. \& HIRAI, K. (1989). Genetic diversity of avian and mammalian Chlamydia psittaci strains and relation to host origin. Journal of Bacteriology 171, 2850-2855.

Girjes, A. A., Hugall, A. F., Timms, P. \& Lavin, M. F. (1988). Two distinct forms of Chlamydia psittaci associated with disease and infertility in Phascolarctos cinereus (koala). Infection and Immunity 56, $1897-1900$.

Grayston, J. T., Kuo, C. C., Campbell, L. A. \& Wang, S. P. (1989). Chlamydia pneumoniae sp. nov. for Chlamydia sp. strain TWAR. International Journal of Systematic Bacteriology 39, 88-90.

Herring, A. J., Tan, T. W., Baxter, S., INGlis, N. F. \& Dunbar, S. (1989). Sequence analysis of the major outer membrane protein gene of an ovine abortion strain of Chlamydia psittaci. FEMS Microbiology Letters 65, 153-158.

Herring, A. J., TAN, T. W. \& BaXTer, S. (1990). Chlamydial abortion in sheep: molecular approaches to vaccination, pathogen detection and strain typing. In Chlamydial Infections, Proceedings of the 7th International Symposium on Human Chlamydial Infections, pp. 378382. Edited by W. R. Bowie, H. D. Caldwell, R. P. Jones, P. Mardh, G. L. Ridgway, J. Schachter, W. E. Stamm \& M. E. Ward. Cambridge: Cambridge University Press.

Holland, S. M., Gaydos, C. A. \& QuinN, T. C. (1990). Detection and differentiation of Chlamydia trachomatis, Chlamydia psittaci and Chlamydia pneumoniae by DNA amplification. Journal of Infectious Diseases 162, 984-987. 
KingSBURY, D. T. \& WeISS, E. (1968). Lack of deoxyribonucleic acid homology between species of the genus Chlamydia. Journal of Bacteriology 96, 1421-1423.

MADELEY, G. R. (1977). Guide pour le prélèvement et le transport des échantillons dans les maladies à virus, Rickettsiae et Chlamydiae. Edited by Organisation Mondiale de la Santé, Genève.

McClenaghan, M., Herring, A. J. \& Aitken, I. D. (1984). Comparison of Chlamydia psittaci isolates by DNA restriction endonuclease analysis. Infection and Immunity 45, 384-389.

McClenaghan, M., Honeycombe, J. R., Bevan, B. J. \& Herring, A. J. (1988). Distribution of plasmid sequences in avian and mammalian strains of Chlamydia psittaci. Journal of General Microbiology 134, 559-565.

McClenaghan, M., Inglis, N. F., Herring, A. J. (1991). Comparison of isolates of Chlamydia psittaci of ovine, avian and feline origin by analysis of polypeptide profiles from purified elementary bodies. Veterinary Microbiology 26, 269-278.

Moulder, J. W., Hatch, T. P., Kuo, C. C., Schachter, J. \& Storz, J. (1984). Genus Chlamydia. In Bergey's Manual of Systematic Bacteriology, vol. 1, pp. 729-739. Edited by N. R. Krieg \& J. G. Holt. Baltimore: Williams \& Wilkins.

Mullis, K. B. (1990). Target amplification for DNA analysis by the polymerase chain reaction. Annales de Biologie Clinique 48, 579-582.

Perez-Martinez, J. A. \& Storz, J. (1985). Antigenic diversity of Chlamydia psittaci of mammalian origin determined by microimmunofluorescence. Infection and Immunity 50, 905-910.

Pickett, M. A., Everson, J. S. \& Clarke, I. N. (1988). Chlamydia psittaci ewe abortion agent: complete nucleotide sequence of the major outer membrane protein gene. FEMS Microbiology Letters 55, 229-234.
Rodolakis, A., Bernard, F. \& Lantier, F. (1989). Mouse models for evaluation of virulence of Chlamydia psittaci isolated from ruminants. Research in Veterinary Science 46, 34-39.

Schachter, J., Banks, J., Sugg, N., Sung, M., Storz, J. \& Meyer, K. F. (1974). Serotyping of Chlamydia. I. Isolates of ovine origin. Infection and Immunity 9, 92-94.

Schachter, J., Banks, J., Sugg, N., Sung, M., Storz, J. \& Meyer, K. F. (1975). Serotyping of Chlamydia: isolates of bovine origin. Infection and Immunity 11, 904-907.

SPEARS, P. \& StORz, J. (1979). Biotyping of Chlamydia psittaci based on inclusion morphology and response to diethylaminoethyldextran and cycloheximide. Infection and Immunity 24, 224-232.

Stephens, R. S., Sanchez-Pescador, R., Wagar, E. A., Inouye, C. \& URDEA, M. S. (1987). Diversity of Chlamydia trachomatis major outer membrane protein genes. Journal of Bacteriology 169, 3879-3885.

Timms, P., Eaves, F. W., Girjes, A. A. \& Lavin, M. F. (1988). Comparison of Chlamydia psittaci isolates by restriction endonuclease and DNA probe analyses. Infection and Immunity 56, 287-290.

Winsor, D. K. \& Grimes, J. E. (1988). Relationship between infectivity and cytopathology for L-929 cells, membrane proteins, and antigenicity of avian isolates of Chlamydia psittaci. Avian Diseases 32, 421-431.

Yuan, Y., Zhang, Y. X., WatKins, N. G. \& Caldwell, H. D. (1988). Nucleotide and deduced amino acid sequences for the four variable domains of the major outer membrane proteins of the 15 Chlamydia trachomatis serovars. Infection and Immunity 57, 1040-1049.

Zhang, Y. X., Morrison, S. G., Caldwell, H. D. \& Baehr, W. (1989). Cloning and sequence analysis of the major outer membrane protein genes of two Chlamydia psittaci strains. Infection and Immunity 57, 1621-1625. 